\title{
Gambaran Perilaku Hidup Bersih dan Sehat (PHBS) di Era Pandemi Corona Virus Disease (COVID-19) di Indonesia
}

\author{
Febby Anugrah Utami, Faridah Sani \\ Fakultas Kesehatan Masyarakat Universitas Indonesia \\ *Korespondensi: Febby Anugrah Utami -febbyanugrahutami@gmail.com
}

\begin{abstract}
Abstrak
Berdasarkan Riskesdas tahun 2018 proporsi anggota rumah tangga yang berperilaku benar cuci tangan dengan benar di Indonesia yaitu 49,8\%, prevalensi merokok penduduk umur > 10 tahun di Indonesia sebanyak $29,3 \%$. Jumlah kasus positif Covid-19 di Indonesia sampai tanggal 10 Januari 2021 yaitu 828.026 kasus dengan angka kematian 24.129 dan angka kesembuhan 681.024 orang. Untuk mencegah penularan Covid-19 dapat dilakukan dengan menerapkan Perilaku Hidup Bersih dan Sehat (PHBS). Tujuan dari penelitian ini yaitu menjelaskan gambaran Perilaku Hidup Bersih dan Sehat (PHBS) dalam mencegah penularan Corona Virus Disease (Covid-19) di Indonesia. Metode yang digunakan dalam penelitian ini adalah metode tinjauan kepustakaan (literatur review). Pada penelitian tinjauan kepustakaan ini ditelusuri 8 jurnal nasional baik yang berbahasa Indonesia maupun yang diterjemahkan ke dalam bahasa Inggris dengan kriteria metode penelitian bersifat kuantitatif. Perilaku Hidup Bersih dan Sehat (PHBS) diterapkan pada berbagai lapisan masyarakat seperti masyarakat umum, mahasiswa, dan anak-anak. Persentase cuci tangan dengan benar di masyarakat pada masa pandemi Covid-19 sudah mencapai 89\%. Persentase mahasiswa yang menerapkan kebersihan diri pada masa pandemi Covid 19 sebanyak 53,41\%. Anak-anak yang sudah membiasakan cuci tangan sebelum makan dan sudah beraktivitas sudah cukup banyak. Berdasarkan hasil systematic review dapat dsimpulkan persentase Perilaku Hidup Bersih dan Sehat (PHBS) pada masa pandemi Covid-19 di masyarakat yaitu sebanyak 52-77,5\%. Persentase Perilaku Hidup Bersih dan Sehat (PHBS) pada masa pandemi Covid-19 pada mahasiswa yaitu sebanyak 49,2-53,1\%. Persentase Perilaku Hidup Bersih dan Sehat pada usia anak yaitu sebanyak 50-86,49\%.
\end{abstract}

Keyword: perilaku hidup bersih dan sehat, covid-19, Indonesia

\section{Description of Clean and Healthy Living Behavior (PHBS) in The Corona Virus Disease (Covid-19) Pandemi Era in Indonesia}

\begin{abstract}
Based on the 2018 Riskesdas, the proportion of household members who behave properly in washing their hands properly in Indonesia is 49.8\%, the prevalence of smoking in the population aged \& gt; 10 years in Indonesia is 29.3\%. The number of positive cases of Covid-19 in Indonesia as of January 10, 2021 is 828,026 cases with a death rate of 24,129 and a cure rate of 681,024 people. To prevent the spread of Covid-19, it can be done by implementing a Clean and Healthy Lifestyle (PHBS). The purpose of this study is to explain the description of Clean and Healthy Living Behavior (PHBS) in preventing the transmission of Corona Virus Disease (Covid-19) in Indonesia. The method used in this study is the literature review method. In this literature review research, 8 national journals, both in Indonesian and translated into English, were traced with the criteria of quantitative research methods. Clean and Healthy Living Behavior (PHBS) is applied to various levels of society such as the general public, students, and children. The percentage of washing hands properly in the community during the Covid-19 pandemic has reached $89 \%$. The percentage of students who apply personal hygiene during the Covid 19 pandemic is $53.41 \%$. There are quite a number of children who have gotten used to washing their hands before eating and have been active. Based on the results of a systematic review, it can be concluded that the percentage of Clean and Healthy Life Behavior (PHBS) during the Covid-19 pandemic in the community was 52-77.5\%. The percentage of Clean and Healthy Life Behavior (PHBS) during the Covid-19 pandemic in students was 49.2$53.1 \%$. The percentage of clean and healthy behavior at the age of children is $50-86.49 \%$.
\end{abstract}

Keywords: sleep quality, diabetes mellitus, risk, lack of sleep 


\section{PENDAHULUAN}

Kantor WHO (World Health Organization) di China melaporkan kasus pneumonia yang tidak diketahui etiologi atau penyebabnya pada tanggal 31 Desember 2019. Kasus pneumonia tersebut ditemukan di Kota Wuhan, Provinsi Hubei, Cina. Kemudian, China mengidentifikasi kasus pneumonia yang tidak diketahui etiologi atau penyebabnya tersebut adalah penyakit yang disebabkan oleh jenis baru coronavirus pada tanggal 7 Januari 2020 (1).

\section{WHO (World Health Organization)} menetapkan kejadian tersebut sebagai Kedaruratan Kesehatan Masyarakat yang Meresahkan Dunia (KMMD)/Public Health Emergency of International Concern (PHEIC) pada tanggal 30 Januari 2020. Kemudian, WHO (World Health Organization) menetapkan Covid-19 sebagai pandemi pada tanggal 11 Maret $2020(1)$.

Peningkatan jumlah kasus berlangsung cukup cepat dan menyebar ke berbagai negara dalam waktu yang singkat (2). Sampai tanggal 10 Januari 2021 jumlah kasus konfirmasi di seluruh dunia adalah 88.120.981 kasus dengan angka kematian 1.914.378 jiwa (1). Jumlah kasus konfirmasi positif Covid-19 di Indonesia sampai tanggal 10 Januari 2021 yaitu 828.026 kasus dengan angka kematian
24.129 dan angka kesembuhan 681.024 orang. Kasus covid-19 di Indonesia terus mengalami kenaikan. Kementerian Kesehatan RI melaporkan bahwa jumlah kasus di Indonesia pada tanggal 9 Januari 2021 yaitu 818.386 kasus dengan jumlah kematian 23.947 dan jumlah kesembuhan 673.511 orang (3).

Belum ada vaksin untuk mencegah penularan Corona Virus Disease (Covid19). Untuk mencegah penularan Covid-19 salah satunya yaitu dengan mencuci tangan dengan sabun dan air mengalir (4). Kegiatan tersebut merupakan salah satu kegiatan dari Perilaku Hidup Bersih dan Sehat (PHBS). Perilaku Hidup Bersih dan Sehat (PHBS) yang dapat mencegah penularan Covid-19 yaitu konsumsi gizi seimbang, istirahat cukup, sering mencuci tangan dengan sabun dan air mengalir, olahraga atau aktivitas fisik, tidak merokok, dan menjaga kebersihan lingkungan (5).

Sementara, menurut laporan Badan Penelitian dan Pengembangan Kesehatan Kementerian Kesehatan Republik Indonesia (Badan Litbangkes Kemenkes RI) tahun 2013 kecenderungan proporsi angota rumah tangga yang berperilaku benar cuci tangan di Indonesia yaitu $47 \%$. Artinya, masih kurang dari setengah masyarakat Indonesia belum menerapkan perilaku cuci tangan dengan benar. Berperilaku benar cuci tangan adalah apabila cuci tangan pakai sabun sebelum 
menyiapkan makan, setiap kali tangan kotor (memegang uang, binatang, dan berkebun), setelah buang air besar, setelah menceboki bayi atau anak, dan setelah menggunakan pestisida atau insektisida, sebelum menyusui bayi, sebelum makan, dan setelah memegang unggas atau binatang (6).

Menurut Data Riset Kesehatan Dasar (Riskesdas) tahun 2018 proporsi anggota rumah tangga yang berperilaku benar cuci tangan dengan benar di Indonesia yaitu 49,8\%. Prevalensi merokok penduduk umur $>10$ tahun di Indonesia sebanyak 29,3\%. Proporsi aktivitas fisik kurang pada penduduk umur $\geq 10$ tahun di Indonesia sebanyak 33,5\%. Proporsi konsumsi buah atau sayur kurang pada penduduk umur $\geq 5$ tahun di Indonesia masih sangat banyak yaitu 95,5\%. Proporsi pengelolaan sampah yang baik di rumah tangga di Indonesia masih kurang yaitu sebanyak 36,8\% (7).

Agar kasus Covid-19 tidak terus mengalami kenaikan, maka perlu adanya langkah pencegahan. Salah satu langkah pencegahan yaitu dengan menerapkan Perilaku Hidup Bersih dan Sehat (PHBS) (8). Sementara Dinas Kesehatan Provinsi Jakarta melaporkan bahwa Persentase Rumah Tangga Ber-PHBS Menurut KabKota Provinsi DKI Jakarta Tahun 2017 yaitu 57,14\%. Artinya baru setengah jumlah rumah tangga yang melakukan Perilaku Hidup Bersih dan Sehat (PHBS) di Provinsi Jakarta (9).
Tujuan dari penelitian ini yaitu peneliti ingin menjelaskan Gambaran Perilaku Hidup Bersih Dan Sehat (PHBS) di Era Pandemi Corona Virus Disease (Covid19) di Indonesia.

\section{METODE}

Metode yang digunakan dalam penelitian ini adalah metode tinjauan kepustakaan (literatur review). Metode tinjauan kepustakaan (literatur review) adalah metode penelitian dengan pengumpulan data pustaka atau penelitian yang kemudian dikaji atau ditinjau secara kritis mengenai pengetahuan, gagasan, dan temuan yang terdapat di dalam data pustaka atau penelitian yang sudah dikumpulkan.

Penelitian ini bersifat deskriptif karena penelitian ini berisi uraian secara teratur data pustaka atau penelitian lain yang diperoleh, kemudian dibahas dan dijelaskan kembali agar dapat dipahami dengan baik oleh pembaca. Pada penelitian tinjauan kepustakaan ini ditelusuri 8 jurnal nasional yang berbahasa Indonesia maupun jurnal nasional yang diterjemahkan ke dalam bahasa Inggris. Mesin pencari yang dipakai yaitu Google Scholar. Kata kunci yang digunakan dalam pencarian adalah Perilaku Hidup Bersih dan Sehat dan Covid-19.

Kriteria inklusi dari penelitian ini terbatas pada jurnal penelitian yang 
menjelaskan mengenai gambaran Perilaku Hidup Bersih Dan Sehat (PHBS) di era pandemi Covid-19 di Indonesia, jurnal nasional berbahasa Indonesia maupun jurnal nasional yang diterjemahkan ke dalam bahasa Inggris, serta jurnal dengan metode penelitian kuantitatif. Kriteria eksklusi dari penelitian ini adalah jurnal yang menjelaskan gambaran pencegahan Covid-19 selain dari Perilaku Hidup Bersih dan Sehat (PHBS) dan jurnal dengan metode penelitian kualitatif. Artikel jurnal yang dijadikan sampel kemudian disajikan dalam tabel dan diidentifikasi.

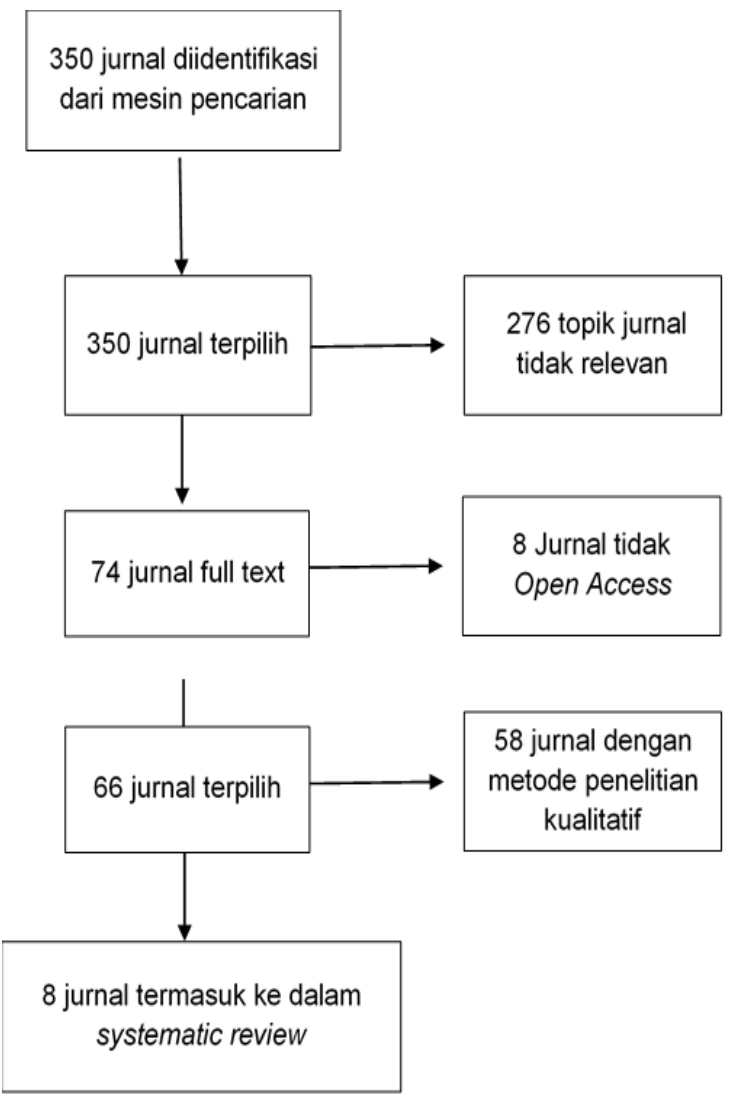

Gambar 1. Proses pemilihan literatur

Didapatkan total 25 jurnal yang kemudian diseleksi kembali dengan kategori inklusi dan kategori eksklusi. Adapun kriteria inklusi yang dimaksud adalah tema sesuai, publikasi dalam waktu 10 tahun terakhir, dapat diakses, serta subjek penelitian merupakan orang dewasa. Sedangkan untuk kategori eksklusinya adalah tersedianya jurnal full text, dan ketersediaan akses terhadap jurnal. Berdasarkan hasil pencarian didapatkan 5 publikasi yang kemudian dianalisis. Proses pemilihan literatur secara rinci dapat diluhat pada Gambar 1.

\section{HASIL}

Rincian literatur berupa judul, nama pengarang, tahun, metode penelitian, hasil penelitian dan penerbit dapat dilihat pada Tabel 1.

Hasil penelitian Maulidia dkk pada anak usia dini selama masa pandemi Covid19 menyebutkan kebiasaan bersih yang sudah dibiasakan pada sebagian besar anak usia 5-7 tahun yaitu membuang sampah jajan ke kotak sampah, memotong kuku dalam satu minggu sekali, mencuci kaki dan tangan dengan sabun setelah beraktivitas dari luar rumah, mencuci tangan dengan air bersih sebelum makan, menggosok gigi ketika mandi dan sebelum tidur. Sedangkan kebiasaan sehat yang sudah dilakukan oleh sebagian besar anak yaitu sarapan sebelum beraktivitas, makan sayur-sayuran serta makan dengan gizi yang seimbang(10) (10). 
Tabel 1. Hasil Temuan Literatur

\begin{tabular}{|c|c|c|c|c|c|}
\hline No. & Judul Penelitian & Peneliti, Tahun & $\begin{array}{c}\text { Metode } \\
\text { Penelitian }\end{array}$ & Tujuan Penelitian & Hasil Penelitian \\
\hline 1. & $\begin{array}{l}\text { Perilaku Hidup Bersih dan } \\
\text { Sehat Mahasiswa } \\
\text { Universitas Mahasaraswati } \\
\text { Denpasar Selama Pandemi } \\
\text { Covid-19 }\end{array}$ & $\begin{array}{l}\text { Ni Putu Udayana } \\
\text { Antari, Ni Putu } \\
\text { Kurnia Dewi, Kadek } \\
\text { Ayu Kartika Putri, } \\
\text { dkk., tahun 2020. } \\
\text { (11) }\end{array}$ & Cross-sectional & $\begin{array}{c}\text { Penelitian ini bertujuan untuk } \\
\text { mengetahui perbedaan perilaku hidup } \\
\text { bersih dan sehat antara mahasiswa } \\
\text { fakultas kesehatan dan mahasiswa } \\
\text { fakultas non-kesehatan di Universitas } \\
\text { Mahasaraswati Denpasar selama } \\
\text { pandemi Covid-19. }\end{array}$ & $\begin{array}{l}\text { Persentase perilaku positif mahasiswa kesehatan } \\
\text { terhadap PHBS adalah } 50,8 \% \text {, sedangkan } \\
\text { mahasiwa fakultas non-kesehatan memiliki } \\
\text { perilaku positif terhadap PHBS sebesar } 49,2 \% \text {. }\end{array}$ \\
\hline 2. & $\begin{array}{l}\text { Gambaran Perilaku Hidup } \\
\text { Bersih dan Sehat dalam } \\
\text { Pencegahan Penularan } \\
\text { Covid-19 }\end{array}$ & $\begin{array}{l}\text { Benny Karuniawati, } \\
\text { Berlina Putrianti, } \\
\text { tahun } 2020(12)\end{array}$ & Deskriptif & $\begin{array}{l}\text { Penelitian ini bertujuan untuk } \\
\text { mendapatkan gambaran pelaksanaan } \\
\text { PHBS di masyarakat dalam upaya } \\
\text { pencegahan penularan virus Covid -19 }\end{array}$ & $\begin{array}{l}\text { Hasil penelitian menunjukkan bahwa dari } 71 \\
\text { responden terdapat } 83,1 \% \text { selalu mencuci tangan } \\
\text { setelah keluar rumah, 76,1\% selalu mencuci } \\
\text { tangan sebelum makan, 67,5\% membersihkan } \\
\text { rumah, 95,8\% menggunakan masker, terdapat } \\
47,9 \% \text { sering menjaga jarak aman saat diluar } \\
\text { rumah minimal } 2 \text { meter, 63,4\% tidak berjabat } \\
\text { tangan, 22,5\% masih aktif menghadiri kegiatan } \\
\text { diluar rumah, 80,3\% selalu membuka jendela dan } \\
\text { ventilasi, 45,1\% membersihkan benda yang ada } \\
\text { di rumah dengan cairan pembersih setiap hari, } \\
\text { 71,8\% selalu menyediakan makanan sehat untuk } \\
\text { keluarga, 32,4\% yang selalu dan sering merokok } \\
\text { dimasa pandemi, 43,7\% berolahraga minimal } 30 \\
\text { menit setiap hari, 54,9\% menyiapkan makan } \\
\text { cepat saji untuk keluarga, 95,8\% mencuci buah } \\
\text { dan sayur sebelum dikonsumsi, } 49,3 \% \text { mencuci } \\
\text { tangan setelah memegang uang, } 77,5 \% \text { selalu } \\
\text { membiasakan seluruh keluarga untuk hidup } \\
\text { sehat, 78,9\% mengkonsumsi minimal } 2 \text { liter } \\
\text { cairan dalam sehari, dan } 84,5 \% \text { tidak pernah } \\
\text { melakukan perjalanan ke luar kota. }\end{array}$ \\
\hline
\end{tabular}




\begin{tabular}{cccc}
\hline No. & Judul Penelitian & Peneliti, Tahun & $\begin{array}{c}\text { Metode } \\
\text { Penelitian }\end{array}$ \\
\hline 3. & Peran Edukasi Orang & Anggi Maulida, Umi & Deskriptif \\
& Tua Terhadap PHBS & Hanifah, tahun 2020 & \\
AUD selama Masa & $(10)$ & \\
Pandemi Covid-19 & &
\end{tabular}

4. Asuhan Keperawatan

Komunitas Pada Masalah

PHBS dan Covid-19

Untuk Warga Dusun

Rejeng Desa Bangka Lelak

Kabupaten Manggarai

Nusa Tenggara Timur

\section{Claudia Fariday \\ Dewi, Kornelia \\ Romana Iwa,}

Bonavantura Nursi

Nggarang, tahun

2020 (13)

\section{Tujuan Penelitian}

Penelitian ini bertujuan untuk mengetahui peran edukasi orang tua terhadap perilaku hidup bersih dan sehat kepada anak uisa 5-6 tahun selama masa pandemi Covid-19.

Observasi

Tujuan pelaksanaan pengabdian ini adalah untuk meningkatkan kesadaran masyarakat dalam menjalankan PHBS

dalam rumah tangga

\section{Hasil Penelitian}

Anak usia 5-6 tahun yang sudah melakukan kebiasaan Perilaku Hidup Bersih dan Sehat dengan membuang sampah jajan ke kotak

sampah sebanyak 6 anak (100\%), membiasakan memotong kuku dalam satu minggu sekali sebanyak 5 anak (83\%), membiasakan mencuci

kaki dan tangan dengan sabun setelah beraktivitas dari luar rumah sebanyak 6 anak $(100 \%)$, membiasakan cuci tangan dahulu sebelum makan dengan air bersih sebanyak 6 anak $(100 \%)$. Anak yang terbiasa memakai masker ketika beraktivitas di luar rumah sebanyak 3 anak (50\%). Anak yang terbiasa sarapan sebelum beraktivitas sebanyak 6 anak $(100 \%)$. Anak yang terbiasa makan sayursayuran sebanyak 4 anak (66\%), anak yang terbiasa minum susu setiap hari sebanyak 3 anak (50 \%), anak yang terbiasa selalu minum vitamin sebanyak 3 anak (50\%), anak yang terbiasa makan dengan gizi seimbang sebanyak 6 anak

$$
(100 \%)
$$

Hasil pengkajian dari 50 warga Dusun Rejeng Desa Bangka Lelak Kabupaten Manggarai Nusa Tenggara Timur mengenai sikap terhadap PHBS yaitu warga yang memiliki sikap positif terhadap PHBS sebanyak 26 orang (52\%), sedangkan warga yang memiliki sikap negatif terhadap PHBS sebanyak 24 orang (48\%). Selain pengkajian terhadap sikap PHBS, pengkajian juga dilakukan terhadap perilaku PHBS seperti mencuci tangan dengan air bersih dan sabun, ASI eksklusif, tidak merokok, beraktifitas fisik, menggunakan air bersih dan jamban. Warga yang memiliki perilaku PHBS baik sebanyak 29 orang (58\%), sedangkan warga yang memiliki perilaku PHBS kurang baik sebanyak 21 orang (42\%) 


\begin{tabular}{|c|c|c|c|c|c|}
\hline No. & Judul Penelitian & Peneliti, Tahun & $\begin{array}{c}\text { Metode } \\
\text { Penelitian }\end{array}$ & Tujuan Penelitian & Hasil Penelitian \\
\hline 5. & $\begin{array}{l}\text { Perilaku Hidup Bersih dan } \\
\text { Sehat Mahasiswa } \\
\text { Pendidikan Olahraga } \\
\text { Universitas Negeri } \\
\text { Yogyakarta Saat Pandemi } \\
\text { Covid-19 }\end{array}$ & $\begin{array}{l}\text { Jaka Sunardi, Erwin } \\
\text { Setyo Kriswanto, } \\
\text { tahun } 2020(14)\end{array}$ & $\begin{array}{l}\text { Deskriptif } \\
\text { kuantitatif }\end{array}$ & $\begin{array}{c}\text { Penelitian ini bertujuan untuk } \\
\text { menganalisis tingkat Perilaku Hidup } \\
\text { Bersih dan Sehat (PHBS) mahasiswa } \\
\text { Pendidikan Olahraga Universitas } \\
\text { Negeri Yogyakarta }\end{array}$ & 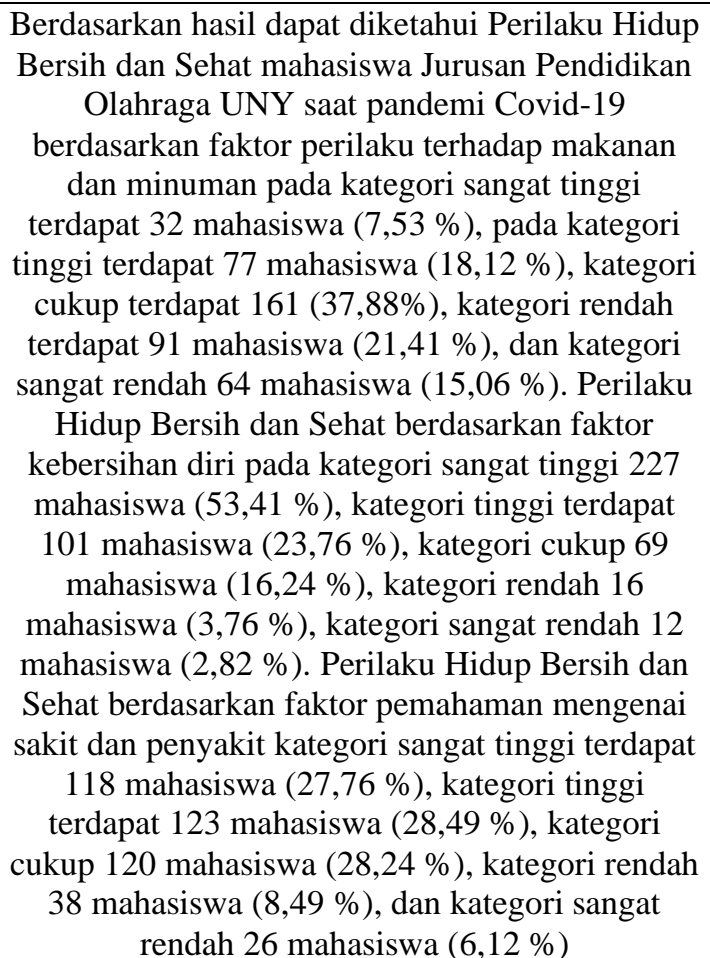 \\
\hline
\end{tabular}


Hasil penelitian Antari dkk () pada mahasiswa Universitas Mahasaraswati, persentase perilaku positif mahasiswa kesehatan terhadap PHBS lebih tinggi dibandingkan mahasiswa non-kesehatan (11). Selain itu, hasil penelitian Sunardi pada mahasiswa jurusan Pendidikan Olahraga Universitas Yogyakarta menyebutkan bahwa sebagian besar mahasiswa melakukan PHBS tersebar pada kategori cukup, tinggi dan sangat tinggi (14).

Sedangkan hasil penelitian pada kelompok masyarakat untuk melihat gambaran perilaku hidup bersih dan sehat yang banyak dilakukan untuk mencegah penularan Covid-19 di antaranya mencuci tangan setelah keluar rumah dan sebelum makan, membersihkan rumah, menyediakan makanan sehat untuk keluarga serta mencuci buah dan sayur sebelum dikonsumsi (12).

Hasil pengabdian oleh Dewi dkk, diketahui bahwa sikap warga dalam menghadapi Covid-19 setuju dan sangat setuju terhadap upaya pencegahan penularan Covid-19. Namun, sikap dan perilaku terhadap PHBS masih dinilai kurang. Intervensi yang dilakukan berupa pendidikan kesehatan tentang PHBS dan Covid-19 dengan harapan kesadaran masyarakat untuk mandiri melakukan pemeliharan kesehatan dengan pola hidup bersih dan sehat serta tetap mentaati peraturan pemerintah yang berhubungan dengan pencegahan penularan Covid-19 tidak meluas (13).

\section{PEMBAHASAN}

Penelitian mengenai gambaran Perilaku Hidup Bersih dan Sehat (PHBS) dilakukan pada berbagai lapisan masyarakat, salah satunya adalah lapisan masyarakat umum. Pada penelitian Karuniawati dan Putrianti (2020) tentang penerapan Perilaku Hidup Bersih dan Sehat (PHBS) untuk mencegah Covid-19 di masyarakat menunjukan hasil $68 \%$ responden sudah tidak pernah melakukan jabat tangan dengan orang lain. Tangan adalah salah satu bagian tubuh yang sering menjadi kontak dengan benda asing atau orang lain yang mungkin saja terdapat virus corona. Tidak berjabat dengan orang lain dan bersentuhan tangan dengan orang lain menjadi alternatif untuk menghindari penularan virus corona (12).

Sementara itu pada penelitian Wirawati, Prihati, dan Supriyanti (2020) mengenai analisis Perilaku Hidup Bersih dan Sehat di Kabupaten Baru di Kotawaringin Barat menunjukan hasil bahwa masyarakat yang selalu menerapkan social distancing dan menghindari kerumunan masih sedikit yaitu dari 50 orang hanya sebanyak 9 orang (17\%) (15). 
Pada penelitian Karuniawati dan Putrianti (2020) tentang penerapan Perilaku Hidup Bersih dan Sehat (PHBS) untuk mencegah Covid-19 di masyarakat dijelaskan bahwa 77,5\% responden sudah menerapkan Perilaku Hidup Bersih dan Sehat (12). Sedangkan pada penelitian Dewi, Iwa, dan Nggarang (2020) menuliskan bahwa hasil pengkajian dari 50 warga Dusun Rejeng Desa Bangka Lelak Kabupaten Manggarai Nusa Tenggara Timur mengenai sikap terhadap PHBS pada pandemi Covid-19 yaitu warga yang memiliki sikap positif terhadap PHBS sebanyak 26 orang (52\%). Warga yang memiliki perilaku PHBS baik sebanyak 29 orang (58\%) (13).

Kemudian pada penelitian Karuniawati dan Putrianti (2020) 71,8\% responden sudah mengkonsumsi makanan yang sehat dan bergizi. Pemenuhan gizi dalam makanan yang dikonsumsi, dapat meningkatkan daya tahan tubuh dan kesehatan tubuh sehingga tidak mudah diserang penyakit. Artinya, sudah banyak masyarakat yang mengkonsumsi makanan yang sehat dan bergizi selama pandemi Covid-19 (12). Hasil penelitian tersebut sejalan dengan hasil penelitian Budiningsih, Siregar, dan Ali (2020) yaitu masyarakat yang mengkonsumsi makanan bergizi selama pandemi sebanyak 86,3\% (16). Kemudian menurut penelitian Wirawati, Prihati, dan Supriyanti (2020) masyarakat yang selalu mengkonsumsi vitamin sebanyak 7 orang (14\%), masyarakat yang selalu mencuci buah dan sayur sebelum dikonsumsi sebanyak 33 orang (66\%) (15).

Penelitian Karuniawati dan Putrianti (2020) hasil penelitian tersebut menyebutkan bahwa $42 \%$ responden sudah tidak pernah merokok. Merokok dapat meningkatkan risiko keparahan penyakit akibat virus corona (12). Pada penelitian Budiningsih, Siregar, dan Ali (2020) persentase masyarakat yang tidak merokok saat pandemi yaitu sebanyak 83\% (16).

Penelitian Wirawati, Prihati, dan Supriyanti (2020) menjelaskan bahwa masyarakat yang selalu mencuci tangan setelah beraktivitas sebanyak 10 orang (20\%) (15). Sementara pada penelitian Budiningsih, Siregar, dan Ali (2020) masyarakat yang menerapkan perilaku mencuci tangan pada masa pandemi sudah lebih banyak yaitu $89 \%$. Penelitian tersebut menunjukan persentase yang lebih banyak dibandingkan data Riskesdas pada tahun 2018 yaitu proporsi anggota rumah tangga yang berperilaku benar cuci tangan dengan benar di Indonesia yaitu 49,8 \% (16).

Pada penelitian Budiningsih, Siregar, dan Ali (2020) masyarakat yang beraktivitas fisik rutin dan cukup istirahat selama pandemi sebanyak 78,2\% serta masyarakat yang menjaga kebersihan lingkungan selama pandemi sebanyak $80 \%$ (16). 
Hasil penelitian Wirawati, Prihati, dan Supriyanti (2020) menunjukan dari 50 orang sampel masyarakat Kabupaten Baru, Kotawaringin Barat yang selalu memakai masker sebanyak 12 orang (24\%), masyarakat yang selalu menutupi hidung menggunakan tisu atau lengan bagian atas ketika bersin sebanyak 17 orang (34\%) (15).

Penelitian mengenai Gambaran Perilaku Hidup Bersih dan Sehat (PHBS) pada masa pandemi Covid-19 juga dilakukan pada populasi mahasiswa. Persentase perilaku positif mahasiswa kesehatan di Universitas Mahasaraswati Denpasar terhadap Perilaku Hidup Bersih dan Sehat (PHBS) adalah 50,8\%, sedangkan mahasiswa fakultas nonkesehatan memiliki perilaku positif terhadap Perilaku Hidup Bersih dan Sehat (PHBS) sebesar 49,2\% (11).

Sementara menurut penelitian Sunardi dan Kriswanto (2020) dapat diketahui perilaku hidup bersih dan sehat mahasiswa Jurusan Pendidikan Olahraga Universitas Neger Yogyakarta saat pandemi Covid-19 berdasarkan faktor perilaku terhadap makanan dan minuman pada kategori sangat tinggi terdapat 32 mahasiswa (7,53\%), pada kategori tinggi terdapat 77 mahasiswa $(18,12 \%)$, kategori cukup terdapat 161 (37,88\%), kategori rendah terdapat 91 mahasiswa $(21,41 \%)$, dan kategori sangat rendah 64 mahasiswa $(15,06 \%)(14)$.

Perilaku hidup bersih dan sehat berdasarkan faktor kebersihan diri pada kategori sangat tinggi 227 mahasiswa $(53,41 \%)$, kategori tinggi terdapat 101 mahasiswa $(23,76 \%)$, kategori cukup 69 mahasiswa (16,24\%), kategori rendah 16 mahasiswa $(3,76 \%)$, kategori sangat rendah 12 mahasiswa (2,82\%). Perilaku hidup bersih dan sehat berdasarkan faktor pemahaman mengenai sakit dan penyakit kategori sangat tinggi terdapat 118 mahasiswa (27,76\%), kategori tinggi terdapat 123 mahasiswa $(28,49 \%)$, kategori cukup 120 mahasiswa (28,24\%), kategori rendah 38 mahasiswa $(8,49 \%)$, dan kategori sangat rendah 26 mahasiswa $(6,12 \%)(14)$.

Penelitian mengenai gambaran Perilaku Hidup Bersih dan Sehat (PHBS) pada masa pandemi Covid-19 juga dilakukan pada anak usia dini. Penelitian Maulida dan Hanifah (2020) mengenai peran edukasi orang tua terhadap Perilaku Hidup Bersih dan Sehat (PHBS) AUD (Anak Usia Dini) menunjukan selama masa pandemi Covid-19 anak usia 5-6 tahun yang sudah melakukan kebiasaan perilaku hidup bersih dan sehat dengan membuang sampah jajan ke kotak sampah sebanyak 6 anak (100\%), membiasakan memotong kuku dalam satu minggu sekali sebanyak 5 anak (83\%), membiasakan mencuci kaki dan tangan dengan sabun setelah beraktivitas 
dari luar rumah sebanyak 6 anak (100\%), membiasakan cuci tangan dahulu sebelum makan dengan air bersih sebanyak 6 anak $(100 \%)(10)$.

Anak yang terbiasa memakai masker ketika beraktivitas di luar rumah sebanyak 3 anak (50\%). Anak yang terbiasa sarapan sebelum beraktivitas sebanyak 6 anak $(100 \%)$. Anak yang terbiasa makan sayursayuran sebanyak 4 anak (66\%), anak yang terbiasa minum susu setiap hari sebanyak 3 anak (50\%), anak yang terbiasa selalu minum vitamin sebanyak 3 anak (50\%), anak yang terbiasa makan dengan gizi seimbang sebanyak 6 anak (100\%) (10).

Kemudian penelitian mengenai pengetahuan Perilaku Hidup Bersih dan Sehat (PHBS) pada usia anak digambarkan pada penelitian Zukmadini, Karyadi, dan Kasrin (2020) mengenai edukasi Perilaku Hidup Bersih dan Sehat (PHBS) dalam pencegahan COVID-19 kepada anak-anak di panti asuhan menjelaskan bahwa persentase pengetahuan peserta sebelum diberikan edukasi yaitu sebesar 74,48\% yang kemudian meningkat menjadi $86,49 \%$ setelah diberikan edukasi (17).

\section{KESIMPULAN}

Berdasarkan hasil systematic review dapat dsimpulkan persentase Perilaku Hidup Bersih dan Sehat (PHBS) pada masa pandemi Covid-19 di masyarakat yaitu sebanyak 52-77,5\%. Masyarakat yang mengkonsumi makanan sehat dan bergizi selama masa pandemi Covid-19 sebanyak 71,8-86,3\%. Masyarakat yang tidak merokok saat masa pandemi Covid-19 sebanyak 42-83\%. Masyarakat yang selalu mencuci tangan dengan benar menggunakan sabun dan air mengalir selama pandemi Covid-19 sebanyak 2089\%. Masyarakat yang beraktivitas fisik rutin dan cukup istirahat selama pandemi Covid-19 yaitu sebanyak 78,2\% serta masyarakat yang menjaga kebersihan lingkungan selama masa pandemi Covid-19 yaitu sebanyak $80 \%$. Persentase Perilaku Hidup Bersih dan Sehat (PHBS) pada masa pandemi Covid-19 pada mahasiswa yaitu sebanyak 49,2-53,1\%. Persentase Perilaku Hidup Bersih dan Sehat pada usia anak yaitu sebanyak 50-86,49\%.

Saran yang dapat diberikan yaitu perlu adanya edukasi untuk meningkatkan pengetahuan dan praktik Perilaku Hidup Bersih dan Sehat (PHBS) dalam rangka pencegahan Covid-19 di masyarakat umum. Pemberian edukasi dapat dilakukan secara daring atau melalui media massa. Mahasiswa sebagai agent of change perlu mematuhi Perilaku Hidup Bersih dan Sehat (PHBS) dan berkontribusi untuk meningkatkan Perilaku Hidup Bersih dan Sehat (PHBS) di masyarakat umum. Kampanye bisa dilakukan melalui media sosial atau penyuluhan secara daring. Anak- 
anak sejak dini perlu diberikan edukasi mengenai Perilaku Hidup Bersih dan Sehat (PHBS) melalui cara yang menyenangkan, misalnya melalui video animasi atau komik. Sehingga anak-anak bisa mengerti cara menerapkan Perilaku Hidup Bersih dan Sehat (PHBS) di kehidupan sehari-hari agar dapat terhindar dari Covid-19.

Saran yang diberikan kepada seluruh masyarakat yaitu untuk selalu menerapkan perilaku hidup bersih dan sehat (PHBS) dalam kehidupan sehari-hari, bukan hanya pada saat adanya pandemic COVID-19 saja. Masyarakat terus dihimbau untuk meningkatkan perilaku hidup bersih dan sehat dalam upaya pencegahan penyebaran Covid-19, karena perilaku masyarakat sangat berperan penting dalam penurunan angka penyebaran Covid-19.

\section{DAFTAR PUSTAKA}

1. WHO. Coronavirus (COVID-19) Dashboard [Internet]. WHO. 2020 [cited 2020 Dec 13]. Available from: https://covid19.who.int/

2. Kementrian Kesehatan Republik Indonesia. Keputusan Menteri Kesehatan Nomor HK.01.07/MENKES/382/2020 tentang Protokol Kesehatan Bagi Masyarakat di Tempat dan Fasilitas Umum dalam Rangka Pencegahan dan Pengendalian Corona Virus
Disease 2019 (Covid-19). Jakarta: Kementerian Kesehatan Republik Indonesia; 2020.

3. Kementrian Kesehatan Republik Indonesia. Situasi Terkini Perkembangan Novel Coronavirus (Covid-19). Jakarta; 2020.

4. Gugus Tugas Percepatan Penanganan Covid-19. Buku Saku Pencegahan Masyarakat Produktif Dan Aman Covid 19. Jakarta: Kementerian Kesehatan Republik Indonesia; 2020.

5. Kementerian Kesehatan Republik Indonesia. Perilaku Hidup Bersih dan Sehat [Internet]. Kementerian Kesehatan Republik Indonesia. 2016 [cited 2021 Jan 10]. Available from: https://promkes.kemkes.go.id/phbs

6. Badan Nasional Penanggulangan Bencana. Gambaran Masalah Perilaku Hidup Bersih dan Sehat Masyarakat Indonesia. Jakarta: Badan Nasional Penanggulangan Bencana; 2013.

7. Kementerian Kesehatan RI. Laporan Nasional Riskesdas 2018. Laporan Nasional Riskesdas 2018. Jakarta; 2018.

8. Kementrian Kesehatan Republik Indonesia (Kemenkes RI). Pedoman Pencegahan dan Pengendalian Coronavirus Disease (Covid-19) Revisi Ke-5. Jakarta; 2020.

9. Dinas Kesehatan Provinsi DKI Jakarta. Profil Kesehatan Provinsi 
DKI Jakarta Tahun 2017. Jakarta; 2017.

10. Maulidia A, Hanifah U. Peran Edukasi Orang Tua terhadap PHBS AUD selama Masa Pandemi Covid19. Musamus J Prim Educ. 2020;3(1):35-44.

11. Antari NPU, Dewi NPK, Putri KAK, Rahayu LRP, Wulandari NPNK, Ningsih NPAW, et al. Perilaku Hidup Bersih dan Sehat Mahasiswa Universitas Mahasaraswati Denpasar Selama Pandemi Covid-19. J Ilm Medicam. 2020;6(2):94-9.

12. Karuniawati B, Putrianti B. Gambaran Perilaku Hidup Bersih dan Sehat dalam Pencegahan Penularan Covid19. J Kesehat Karya Husada. 2020;8(2):112-31.

13. Dewi CF, Iwa KR, Nggarang BN. Asuhan Keperawatan Komunitas Pada Masalah PHBS dan COVID-19 pada Warga Dusun Rejeng Desa Bangka Lelak Kabupaten Manggarai Nusa Tenggara Timur. Randang Tana J Pengabdi Masy. 2020;3(3):148-57.

14. Sunardi J, Kriswanto ES. Perilaku Hidup Bersih dan Sehat Mahasiswa Pendidikan Olahraga Universitas Negeri Yogyakarta saat pandemi Covid-19. J Pendidik Jasm Indones. 2020 Nov;16(2):156-67.

15. Wirawati MK, Prihati DR, Supriyanti E. The Analysis of Clean and Healty
Behaviours in the Family In Preventing Covid-19 Transmission. J Keperawatan. 2020;12(4):967-76.

16. Budiningsih $M$, Siregar N, Ali M. People's Clean and Healthy Behaviors during the COVID-19 Outbreak: A Case Study in DKI Jakarta Province. In: Proceedings of the 5th International Seminar of Public Health and Education. Semarang: European Alliance for Innovation; 2020. p. 347-54.

17. Zukmadini AY, Karyadi B, Kasrina K. Edukasi Perilaku Hidup Bersih dan Sehat (PHBS) dalam Pencegahan COVID-19 Kepada Anak-Anak di Panti Asuhan. J Pengabdi Magister Pendidik IPA. 2020;3(1):68-76. 